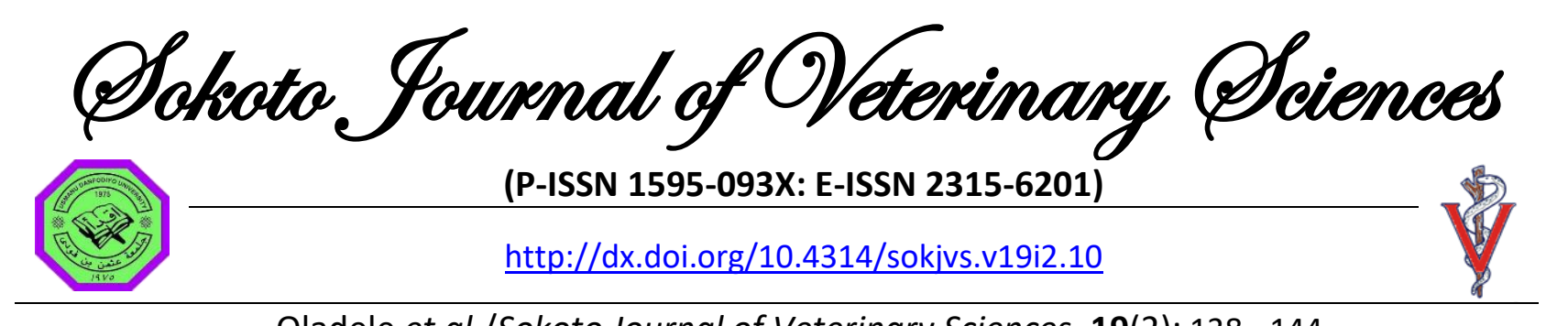

Oladele et al./Sokoto Journal of Veterinary Sciences, 19(2): 138 - 144.

\title{
Mortality of Clarias gariepinus caused by Aeromonas caviae and nitrite toxicity in a fish farm
}

\author{
OO Oladele ${ }^{1 *}$, NO Ameji ${ }^{1}$, GY Gurumyen ${ }^{2}$, WA Adanu ${ }^{3}$, TT Kolade ${ }^{4}$, OA \\ Agbato $^{5}$ \& LH Lombin ${ }^{3}$ \\ 1. Department of Veterinary Medicine, Surgery and Radiology, Faculty of Veterinary Medicine, University of \\ Jos, Nigeria \\ 2. Department of Veterinary Microbiology and Pathology, Faculty of Veterinary Medicine, University of Jos, \\ Nigeria \\ 3. Department of Veterinary Public Health and Preventive Medicine, Faculty of Veterinary Medicine, \\ University of Jos, Nigeria \\ 4. Department of Biological Sciences, Yaba College of Technology, Yaba Lagos, Nigeria
5. Veterinary Diagnostic Laboratory, Animal Care Services Konsultnig Limited, Abuja, Nigeria
}

*Correspondence: Tel.: +2348033823237; E-mail: oludotunoladele@gmail.com

Copyright: (C) 2021

Oladele et al. This is an open-access article published under the terms of the Creative Commons Attribution License which permits unrestricted use, distribution, and reproduction in any medium, provided the original author and source are credited.

Publication History: Received: 24-11-2020 Revised: 25-04-2021 Accepted: 03-05-2021

\section{Abstract}

In Nigeria, farming of freshwater fish, mainly that of Clarias gariepinus has gained prominence as means of improved protein supply and livelihood. Many farmers suffer untold losses in their bid to make a living from commercial fish production. Among the major causes of infectious disease outbreaks in fish farms are pathogenic bacteria of the genus Aeromonas. This is a case report of outbreak of Aeromonas caviae infection complicated by nitrite toxicity in Clarias gariepinus. Carcasses of 17 African catfish juveniles and two water samples were presented to the poultry and fish clinic of the Veterinary Teaching Hospital, University of Jos for investigation. The fishes had been on medication (Fish cure antibiotic $+^{\circledR}$ ) for over 5 days with cumulative mortality of 230 out of 2,500 fishes (9.2\%). Necropsy was conducted and samples were taken for microbial analysis and histopathology while water samples were subjected to chemical analysis. Gross lesions were broken barbels, cutaneous depigmentation, branchial pallor, ascites, renal and splenic congestion. Histologically, there was dissociation of hepatic cords, necrosis of hepatocytes with vacuolation and mononuclear cellular infiltrations. Also, there was renal tubular epithelial necrosis with mononuclear and heterophilic infiltration while micro abscesses were observed in the brain. Marked Zenker's necrosis and edema were seen in the skeletal muscles. Organism isolated from livers and kidneys was identified as Aeromonas caviae and was susceptible to enrofloxacin, furaltadone and florfenicol. Nitrite in fish pond water was $1 \mathrm{mg} / \mathrm{L}$. Bath medication with enrofloxacin at $33 \mathrm{mg} /$ litre of water for 6 hours treatment per day was done to reduce the mortality. The farmer was advised to change the source of water for the fish pond immediately. It is recommended that to avoid losses in fish farming, farmers should check the quality of water intended for use on fish farms and ensure early health check on fingerlings purchased for rearing.

Keywords: Aeromonas, Catfish, Enrofloxacin, Mortality, Nitrite toxicity 


\section{Introduction}

The culture of African catfish (Clarias gariepinus) by more farmers has been encouraged by factors like acceptability of the fish species as a good source of protein, its good growth with good feed conversion ratio under optimum culture conditions, its resistance to stress as well as good export value of the well processed fish. Many grow-out fish farmers buy catfishes as fingerlings or juveniles to stock in different types of ponds. The growth period of the fish is often influenced by health status from the hatchery source, stocking density, water quality management on the farm, type and quality of the feed given and level of compliance with biosecurity.

Disease outbreaks that occur in fish farms are usually associated with abiotic or biotic factors (Molnar et al., 2019). The abiotic factors are noninfectious conditions such as water quality issues (ammonia toxicity, nitrite toxicity, shortage of dissolved oxygen, very low or high temperature) and nutritional deficiencies. Biotic factors are parasites, fungi, viruses and bacteria (Molnar et al., 2019). Globally, the scourge of bacterial disease outbreaks in the aquaculture industry remains a deep concern to the stakeholders. These disease outbreaks in fish farms often result in high economic losses as a result of high mortality rates and resultant poor growth of the survivors. Ikpi \& Offem (2011) reported that the major causes of catfish mortalities in Africa are bacterial diseases. In the United States of America, approximately $60 \%$ of loses in catfish farms were as a result of single or mixed bacterial infections, $30 \%$ resulted from parasitic infestations, 9\% from fungal infections, and $1 \%$ were caused by viruses (MSU, 2020).

One of the common conditions caused by Aeromonas infection in freshwater fish is hemorrhagic septicaemia, particularly due to Aeromonas hydrophila which is a Gram-negative rod shaped and oxidase positive bacterium (Austin \& Austin, 2007).

Haemorrhagic septicaemia is characterised by the presence of lesions on fish surface which may lead to the sloughing-off of scales, local haemorrhages particularly in the vent and gills, ulcers, abscesses, exophthalmia and abdominal distension with ascitic fluid. Also, generalized liquefaction of the internal organs and musculature could be seen (Austin \& Austin, 2007).

Other species of Aeromonas known to be pathogenic to fish are A. veronii, A. caviae, A. sobria, A. piscicola, A. schubertii and $A$. jandaei (Austin \& Austin, 2007).
One of the anomalies in fish culture water that can result in sudden high mortality especially in freshwater fishes is a build-up of the nitrite content. Since marine and estuarine water bodies contain high levels of salt, nitrite toxicity is not common with the saltwater fishes (Boyd, 2014). The 96 hours LC50 of nitrite varies in different species of fish. In marine species like sea trout it is as high as $980 \mathrm{mg} / \mathrm{L}$ while in freshwater species like rainbow trout and in cutthroat trout, it is 0.24 to $11 \mathrm{mg} / \mathrm{L}$ (ppm) and 0.5$0.6 \mathrm{mg} / \mathrm{L}$ respectively (Boyd, 2014). Nitrite is an intermediate compound in the oxidation of ammonia nitrogen to nitrate (Boyd, 2014) by nitrifying bacteria like Nitrosomonas and Nitrobacter species. It is considerably more toxic than nitrate. The build-up of nitrite in pond water results in its uptake via the gills to combine with hemoglobin to form methemoglobin which cannot take up oxygen, thus resulting in tissue hypoxia/anoxia even if there is sufficient dissolved oxygen in the pond. (Boyd, 2014). This condition is called nitrite poisoning or brown blood disease. Nitrite concentration in the blood could be 60 times higher than the concentration in fish pond water (Fontenot \& Isely, 1999) and it is known to accumulate in other tissues like gills, liver, brain and muscle. Nitrite levels can rise quickly in less than 24 hours in catfish ponds with fatal consequences (Johnson, 1993). This report is an account of the interplay between one of the afore-mentioned biotic factors and an abiotic factor resulting in high mortalities.

\section{Case History}

On the 23rd of July 2020, a farmer presented 15 carcasses of his catfish juveniles and two water samples one of them contained two fishes taken from the fish pond and the other was from the borehole where water is sourced for the fish pond. These samples were brought to the Poultry and Fish clinic of the Veterinary Teaching Hospital, University of Jos, Plateau State, Nigeria for investigations. The chief complaint was persistent mortality of the fishes for 8 days earlier when they were received from a catfish hatchery based in Kaduna, Kaduna state, Nigeria. As at the time of presentation, the cumulative mortality was already 230 juveniles in a stock of 2,500 catfish juveniles. The fishes were stocked in a concrete tank of $4 \mathrm{~m} \times 2 \frac{1}{2} \mathrm{~m} \times 1.2 \mathrm{~m}$ dimension and fed on Coppens ${ }^{\circledR} 0.8 \mathrm{~mm}$ floating commercial feed, manufactured by Coppens international in Helmond, The Netherlands. The feed consists of the following: $56 \%$ crude protein, $15 \%$ 
fat, $0.2 \%$ crude fibre, $13 \%$ ash and $1.89 \%$ total phosphorus.

On the day of presentation to the Clinic, 58 catfishes were already dead despite the medication with Fish cure antibiotic ${ }^{\circledR}$ (Rehob Multibusiness \& Services limited, Ikotun Lagos) administered by bath for over 5 days. This drug is composed of $10 \%$ oxytetracycline, $5 \%$ streptomycin and $2 \%$ Vitamin C. Out of the 58 catfishes that died, 15 were presented in a plastic container, apart from the two that were brought in a transparent bottle containing the pond water.

\section{Clinical Examination}

The live but weak fish in the transparent bottle had slight cutaneous depigmentation and was hanging

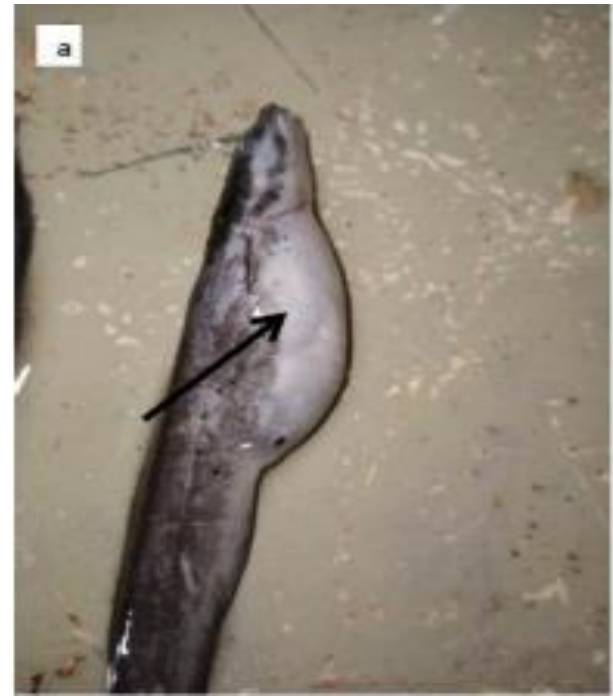

Plate 1a: Black arrow showing swollen abdomen (ascites) in catfish juvenile



Plate 2: Congested kidney (white arrow) in catfish juvenile from fish farm

vertically in the water while the other fish was lying down dead at the base of the container.

\section{Post Mortem Examination}

The dead fishes presented were found to have broken barbels, cutaneous depigmentation, pale gills seen below the operculum and two of them had ascites (Plates $1 \mathrm{a}$ and $1 \mathrm{~b}$ ) with mild erythema of the ventral area. The average total length and weight of the carcasses were $6.95 \pm 0.67 \mathrm{~cm}$ and $2.51 \pm 0.68 \mathrm{~g}$ respectively. Scrapings from skin and gill snips were taken for microscopic examination for parasites. A mid-ventral incision was made to expose the viscera. The lesions observed were slightly pale livers; the kidneys (Plate 2) and spleens were congested; and mild suffusion of the musculature of the abdominal

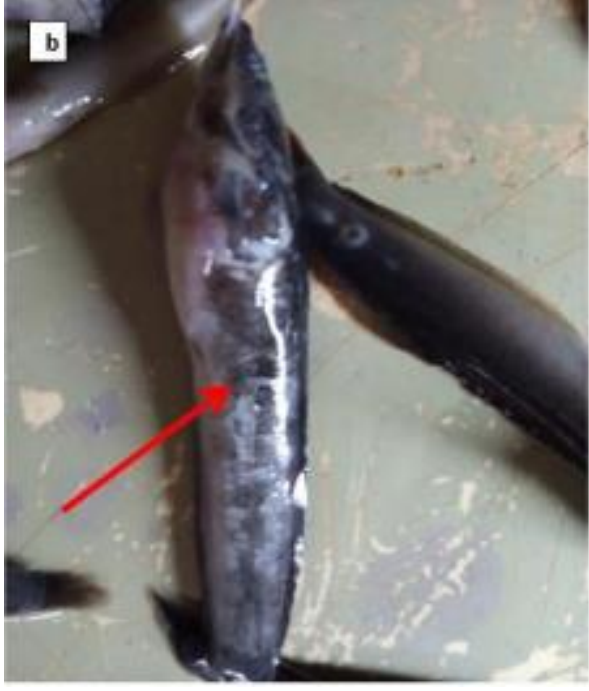

Plate 1b: Red arrow indicating cutaneous depigmentation

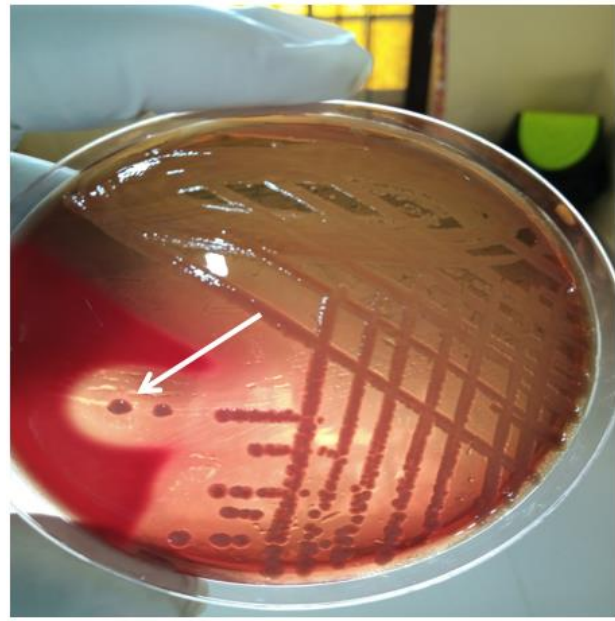

Plate 3: Growth of Aeromonas caviae on $5 \%$ blood agar with hemolytic colonies (arrow) wall. Sterile swabs were used for the collection of samples from the kidneys and livers (after cleaning the surfaces with methylated spiritsoaked cotton wool) for microbial analysis. Eight of the other carcasses were wholly immersed in a $10 \%$ formalin solution for histopathological investigation.

\section{Microbial Analysis} and Histopathology Under sterile condition, swab samples from the kidneys and livers were streaked on sterile $5 \%$ blood agar and MacConkey agar plates and incubated aerobically at $37^{\circ} \mathrm{C}$ for 24 hours. The growth on $5 \%$ blood agar was high with colonies that had $\beta$ hemolysis (Plate 3 ) and on MacConkey 


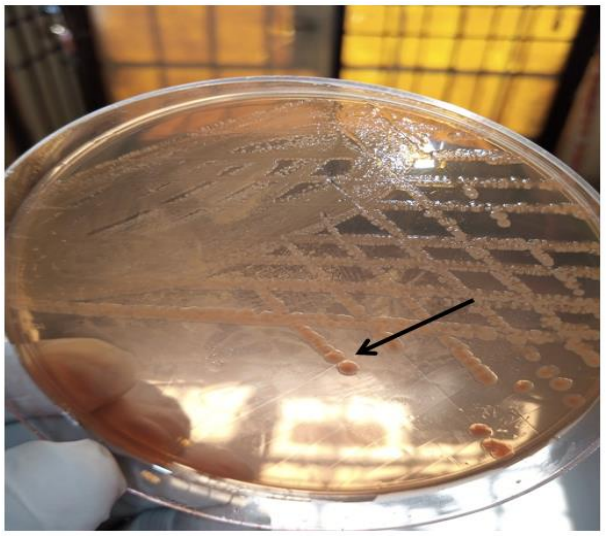

Plate 4: Weak lactose fermenting colonies of Aeromonas caviae (arrow) on MacConkey agar

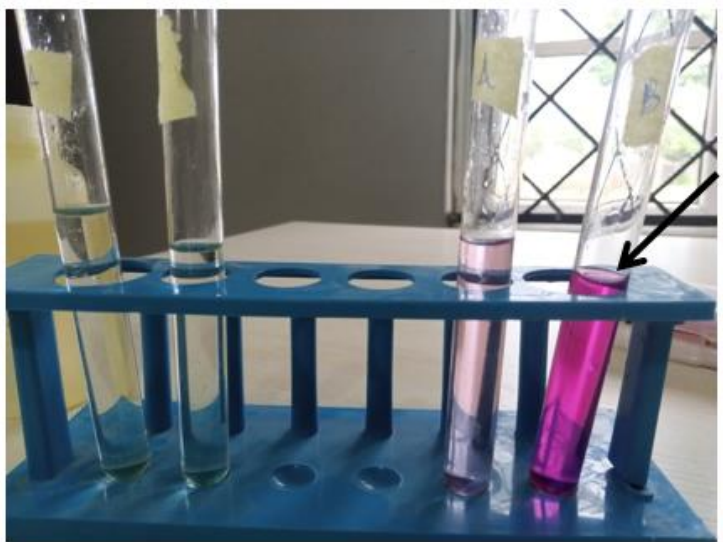

Plate 5: Arrow indicating pond water sample with high nitrite level (purple color)

agar, colonies appeared as weak lactose fermenters (Plate 4). The identification of the $\beta$-hemolytic bacterial isolate on $5 \%$ blood agar was done using Gram staining, oxidase test, catalase and other biochemical tests as described by Chauhan \& Chandra (2007). Pure colonies were inoculated in sterile nutrient broth and the suspension was allowed to be turbid before immersing sterile inoculating loop to pick inoculum to streak and stab triple sugar iron agar and Simmon citrate agar slants. Also $1 \%$ starch agar prepared was streaked with the inoculum and incubated at $37^{\circ} \mathrm{C}$ for growth of the organism prior to starch hydrolysis test. A sterile swab was also immersed into the turbid suspension and used on phenol red agar to seed its surface before placing sugar discs (dextrose, maltose, sucrose and mannitol). This was incubated at $37^{\circ} \mathrm{C}$ for 5 hours for sugar fermentation test (Table 1). Results of the outcome of biochemical tests were inputted online on GIDEON (Global infectious diseases and epidemiology online network) identification platform (gideononline.com/microbiology/main/) and the isolate was identified as Aeromonas caviae.
Table 1. Biochemical tests for bacterial identification of Aeromonas caviae

\begin{tabular}{ll}
\hline Test & Result \\
Gram reaction & Gram negative rods \\
Oxidase & + \\
Catalase & + \\
Dextrose & + \\
Maltose & + \\
Sucrose & + \\
Lactose & + \\
Mannitol & + \\
Urease & + \\
Methyl red & + \\
Voges proskeur & + \\
Indole & + \\
Citrate & - \\
Hydrogen sulphide & - \\
Gas & - \\
Hemolysis & + \\
Starch hydrolysis & + \\
Motility & + \\
Identification & Aeromonas caviae \\
\hline Key: & \\
+ means positive & \\
- means negative & \\
Tahlo &
\end{tabular}

Table 2: Antibiogram of Aeromonas caviae isolated from tissues of catfish juveniles

\begin{tabular}{lcl}
\hline Sensitive & Intermediate & Resistant \\
\hline Enrofloxacin & Gentamicin & Streptomycin \\
Furaltadone & & Colistin \\
Florfenicol & & Oxytetracycline \\
& & Penstrep \\
& & Tylosin \\
\hline
\end{tabular}

The swab from the pure colonies of the nutrient broth was used in seeding the surface of nutrient agar before placing antibiotic discs for the antibiotic susceptibility test using the disc diffusion method. This was incubated for 16 hours at $37^{\circ} \mathrm{C}$ before recording (Table 2 ).

\section{Histopathology Technique}

After dissection, tissues were fixed in $10 \%$ formaldehyde. They were then dehydrated by different concentrations of ethanol $(70 \%, 80 \%, 90 \%$, and $100 \%$, then cleared in xylene, and were embedded in paraffin blocks before sectioning into $5 \mu \mathrm{m}$ thick tissue sections using microtome. The sections were mounted on glass slides and stained with haemotoxylin and eosin (H \& E) stain. 

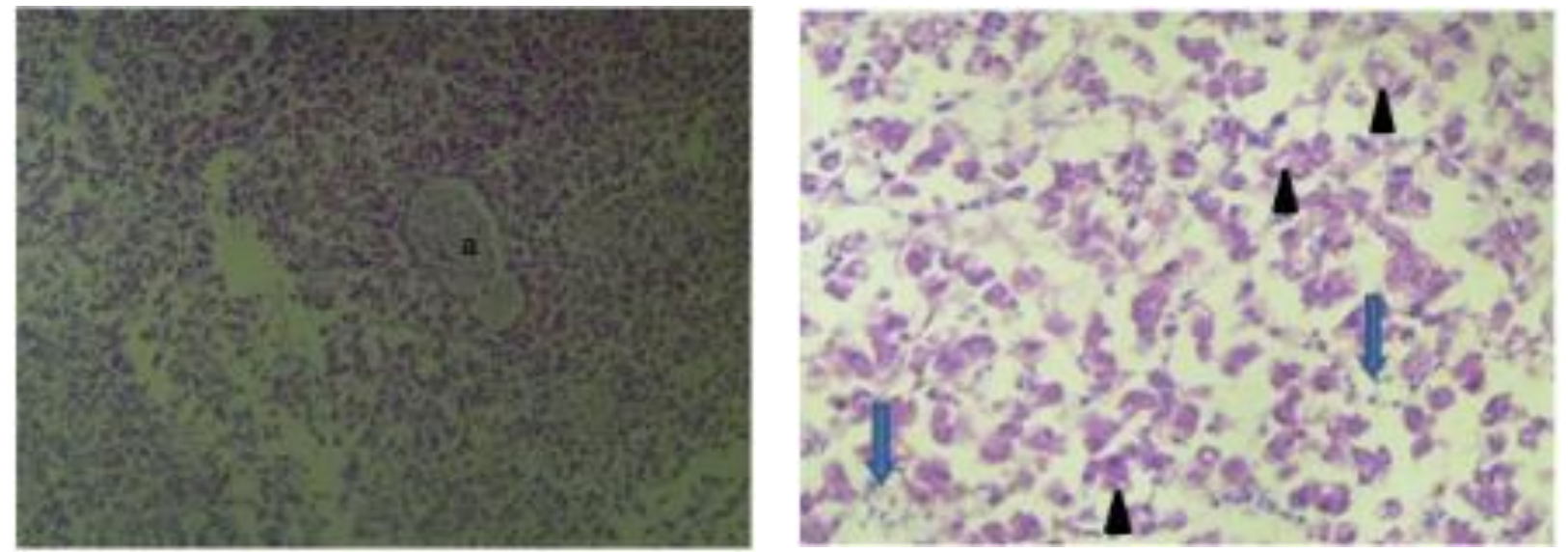

Plate 6: Photomicrograph of fish liver. Dissociation of the hepatic cords and congestion (a) [Obj×100) H\&E]. B. Severe necrosis of hepatocytes and vacuolation (arrow head) with mononuclear cellular infiltrations (arrows) [Obj×400 H\&E]

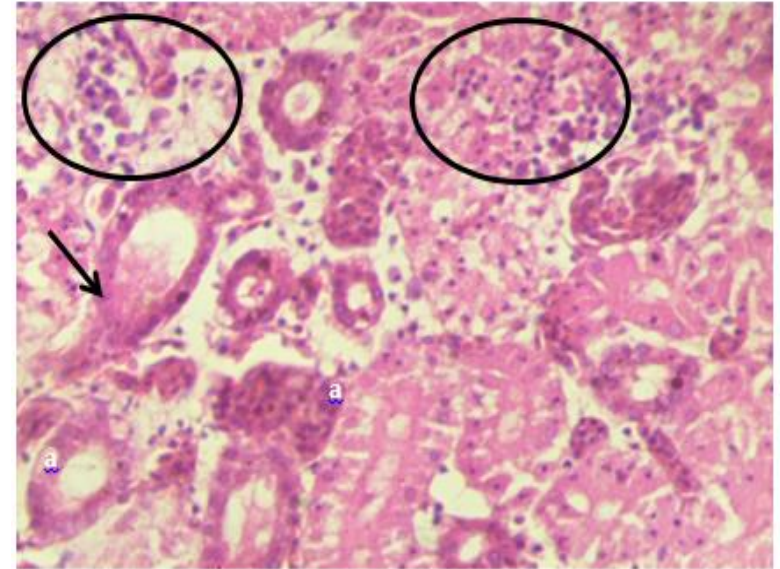

Plate 7: Photomicrograph of the kidney of catfish. Tubular epithelial necrosis (arrow), mononuclear, and heterophil infiltration (highlighted) [Obj×400 H\&E]

The histopathology of the liver of dead Clarias gariepinus revealed dissociation of hepatic cords, congestion and severe necrosis of hepatocytes with vacuolation and mononuclear cellular infiltrations (Plate 6). The kidney had tubular epithelial necrosis with mononuclear and heterophilic infiltration (Plate 7). Micro abscesses were observed in the brain with marked Zenker's necrosis and edema also seen in the skeletal muscles (Plates 8 and 9) respectively.

\section{Chemical Analysis of Water Samples}

Water samples were subjected to chemical analysis to determine parameters like TDS (total dissolved solids), salinity, $\mathrm{pH}$, and conductivity using digital ambulatory water and soil analysis kit (Labtronics ${ }^{\circledR}$, Panchkula, Haryana India) and other parameters like total ammonia nitrogen (indophenol technique), nitrite, total hardness as well as calcium and magnesium hardness were determined by the titrimetric method (Chattopadhyay, 1998). Optical density values of ammonia and nitrite were determined by

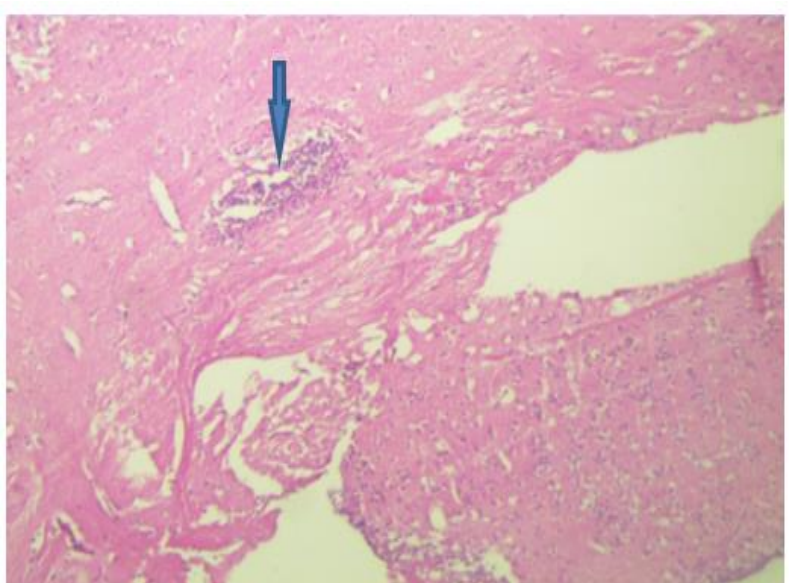

Plate 8: Photomicrograph of the brain of catfish: Presence of micro abscess within the brain (arrow) [Obj $\times 100 \mathrm{H} \& \mathrm{E}$ ]

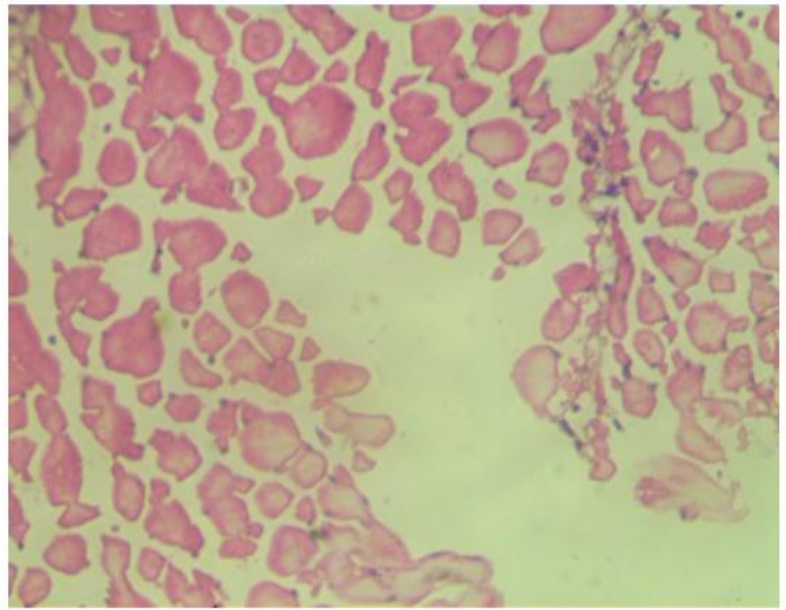

Plate 9: Photomicrograph of the skeletal muscle of catfish. Zenker's necrosis and edema (Obj×400 H\&E)

colorimetry (Model AE-11D, LemfieldMedical, England) and compared with standards as described by Chattopadhyay (1998) (Table 3). 


\section{Management}

Based on the outcome of the antibiotic susceptibility test, Enrocare $\mathrm{BH}^{\circledR}$ (a brand of $20 \%$ Enrofloxacin, Hebei New Century Pharma. Co. Itd, Hebei China) was recommended for medication via feed at $10 \mathrm{mg} / \mathrm{kg}$ body weight for 1 week initially. Being a bitter drug, a saturated sugar solution was used to sweeten it before using the drug to coat the fish feed pellets and sun- dried. On the 4th day of treatment, the farm was visited and it was observed that the fishes were not responding to the presence of feed given to them and the morbidity was high with persistent mortality (Table 4).

The second phase of treatment was started by bath medication using the same Enrofloxacin 20\% at $33 \mathrm{mg} /$ litre of water for 6 hours per day for 5 consecutive days in reduced water volume because of cost. This resulted in a marked reduction in mortality from 127 to 2 by the 4 th day of this phase of the treatment.

However, by the 5 th day, mortality rose to 14 . A day after the end of the second phase of bath medication, mortality rose to 225 fishes which prompted a second check on the water quality that revealed a persistent and significant level of nitrite in the fish tank water and within the source of water (Plate 5). The water had to be changed to reduce exposure of fishes to nitrite and a third phase of treatment was started till mortality significantly dropped by the 4 th day.

\section{Discussion}

Control of bacterial disease outbreaks can be challenging and more expensive especially when the fishes have lost appetite for food (through which medication can be cheaper) with concomitant water quality issues. Management of nitrite toxicity could be done by immediate change of water in the pond and releasing fresh water to which Sodium chroride $(\mathrm{NaC})$ is added (Boyd, 2014).

This is easier to do when there is no nitrite from the water source and the water volume used is not much. The pond in question has a dimension of $4 \mathrm{~m} \times$ $21 / 2 \mathrm{~m} \times 1.2 \mathrm{~m}$ with a total volume of $12 \mathrm{~m}^{3}$, at $75 \%$ capacity of the fish tank, 9,000 litres of water will be held. Using salt in this volume of water at $1 \mathrm{~kg}$ to $2 \mathrm{~kg} / 1,000$ litres, has its economic implication too. The use of salt $(\mathrm{NaCl})$ is based on the principle where chloride ions compete with nitrite at the gill epithelium and hence reduce exposure of fish to nitrite.

The fish pond had a history of normal water change every 2 days except during the days of daily bath medication with enrofloxacin. It was obvious that the nitrite build-up would continue, especially due to uneaten feeds that sank in the pond and dead fishes that were not cleared on time. This led to nitrite toxicity as seen in this case.

The high mortality in this set of fish was also due to the virulence of the bacterium isolated as shown by its hemolytic nature on $5 \%$ blood agar. Aeromonas

Table 3: Result of chemical analysis of water samples

\begin{tabular}{llllllllll}
\hline Source & $\mathrm{pH}$ & $\mathrm{TH}(\mathrm{mg} / \mathrm{l})$ & $\begin{array}{l}\mathrm{Ca}^{2+} \\
(\mathrm{mg} / \mathrm{l})\end{array}$ & $\begin{array}{l}\mathrm{Mg}^{2+} \\
(\mathrm{mg} / \mathrm{l})\end{array}$ & $\begin{array}{l}\mathrm{NO}_{2}^{-} \\
(\mathrm{mg} / \mathrm{l} \\
)\end{array}$ & $\begin{array}{l}\mathrm{NH}_{3}-\mathrm{N}(\mathrm{TAN}) \\
(\mathrm{mg} / \mathrm{l})\end{array}$ & $\begin{array}{l}\text { Conductivity } \\
(\mu \mathrm{S} / \mathrm{cm})\end{array}$ & $\begin{array}{l}\text { TDS } \\
(\mathrm{mg} / \mathrm{l})\end{array}$ & $\begin{array}{l}\text { Salinity } \\
(\mathrm{mg} / \mathrm{l})\end{array}$ \\
\hline $\begin{array}{l}\text { Borehole water } \\
\text { Pond water }\end{array}$ & 8.4 & 37.5 & 15.0 & 22.5 & 0.06 & 0.05 & 144.6 & 93.99 & 140.0 \\
(with dead fish) & 8.4 & 35.0 & 15.0 & 20.0 & 1.00 & 0.10 & 154.7 & 100.5 & 147.0 \\
\hline
\end{tabular}

Key:

TH: Total hardness, $\mathrm{Ca}^{2+}$ : Calcium hardness, $\mathrm{Mg}^{2+}$ : Magnesium hardness, $\mathrm{NO}^{2-}$ : Nitrite, TAN: Total ammonia nitrogen, TDS: Total dissolved solids

Table 4: Mortality pattern of catfish juveniles during phases of treatment with enrofloxacin

\begin{tabular}{llllll}
\hline $\begin{array}{l}\text { Phase 1 } \\
\text { treatment (Feed } \\
\text { medication) }\end{array}$ & $\begin{array}{l}\text { Daily mortality } \\
\text { of catfish }\end{array}$ & $\begin{array}{l}\text { Phase 2 } \\
\text { treatment } \\
\text { (bath medication) }\end{array}$ & $\begin{array}{l}\text { Daily mortality } \\
\text { of catfish }\end{array}$ & $\begin{array}{l}\text { Phase 3 } \\
\text { treatment (bath } \\
\text { medication) }\end{array}$ & $\begin{array}{l}\text { Daily } \\
\text { mortality of } \\
\text { catfish }\end{array}$ \\
\hline Day 1 & 18 & Day 1 & 127 & Day 1 & 225 \\
Day 2 & 13 & Day 2 & 120 & Day 2 & 43 \\
Day 3 & 12 & Day 3 & 55 & Day 3 & 26 \\
Day 4 & 20 & Day 4 & 2 & Day 4 & 20 \\
Day 5 & 38 & Day 5 & 14 & & \\
\hline
\end{tabular}


spp are known to produce hemolysins (Pandey et al., 2010) which may lead to anaemia in affected fish populations. Aeromonas spp also produce proteases as virulence factors as reported by Pandey et al. (2010) and this could have been responsible for the loss of hepatic cords, necrosis of tubular epithelium and zenkers necrosis in skeletal muscles of the juvenile catfishes as in this case. The invasiveness of Aeromonas caviae isolated from the fish tissues was further shown by evidence of inflammatory reaction (micro abscesses) seen in the brain. These findings of lesions of brain damage observed would definitely interfere with growth of survivors of this outbreak.

The recurrent or spikes of mortalities in the face of antibiotic medication observed during this case management were indicators of the far-reaching effects of non-infectious factors on the success of fish farming. Losses from disease outbreaks on fish farms can be avoided or highly minimized when both infectious and non-infectious factors are holistically investigated and handled during disease outbreaks. Conclusively, water quality assessment is important in addition to test for pathogenic organisms in determining the success of fish farming. It is recommended that fish farmers take the first step by testing the quality of water they intend to use and avail themselves of the opportunities to learn the basics in fish farming before venturing into it farming. Also, early check on the health status of newly purchased fingerlings or juveniles will help farmers to avoid blind use of antibiotics as was seen in this case in which the pathogen isolated was found to be resistant to oxytetracycline and streptomycin which were the active ingredients in the first drug the client administered in the first week after buying the fishes.

\section{Conflicts of Interest}

The authors declare no conflict of interest.

\section{References}

Austin B \& Austin DA (2007). Aeromonadaceae Representatives (Motile Aeromonads). In: Bacterial Fish Pathogens- Diseases of Farmed and Wild Fish (fourth edition)
Springer-Praxis publishing, Chichester, UK. Pp 161-214.

Boyd CE (2014). Nitrite toxicity affected by species susceptibility; environmental conditions https://www.aquaculturealliance.org/advoc ate/nitrite-toxicity-affected-by-speciessusceptibility-environmental-conditions, retrieved 24-11-2020.

Chattopadhyay GN (1998). Chemical Analysis of Fish Pond Soil and Water. Daya Publishing House, Daryaganj, Delhi, India. Pp 36-39.

Chauhan RS \& Chandra D (2007). Microbiological Examination of Clinical Specimens in Veterinary Laboratory Diagnosis, (Second edition). International Book Distributing co. Lucknow 226001 UP, India. Pp 131-147.

Fontenot QC \& Isely JJ (1999). Characterization and inhibition of nitrite uptake in shortnose sturgeon fingerlings. Journal of Aquatic Animal Health, 11(1): 76-80.

Ikpi G \& Offem B (2011). Bacterial infection of mudfish Clarias gariepinus (Siluriformes: Clariidae) fingerlings in tropical nursery ponds. Revista de Biología Tropicale, 59 (2): 751-759.

Johnson M (1993). The Veterinary Approach to Channel Catfish. In: Aquaculture for Veterinarians (L Brown, editor), Pergamon Press, Elmsford, New York. Pp 249 - 270.

Molnár K, Székely C \& Láng M (2019). Field guide to the Control of Warm Water Fish Diseases in Central and Eastern Europe, the Caucasus and Central Asia. FAO Fisheries and Aquaculture Circular No.1182. Ankara, FAO. Pp 124. Licence: CC BY-NC-SA 3.0 IGO

Minnesota State University (MSU) (2020). Diseases of catfish. http://extension.msstate.edu/content/dise ases-catfish, retrieved 30-10-2020.

Pandey A, Naik M \& Dubey SK (2010). Hemolysin, protease, and EPS producing pathogenic Aeromonas hydrophila strain An4 shows antibacterial activity against marine bacterial fish pathogens. Journal of Marine Biology, doi.10.1155/2010/563205. 